\title{
Tracer Study of Technical Education Graduates of Osun State College of Education, 2011-2015
}

\author{
Simeon O. Odede ${ }^{\mathrm{a}}$, Adeolu T. Adeyemi, Idayat O. Kolawole, \\ Segun R. Oladimeji, Abayomi O. Adeniyi \\ ${ }^{\text {a }}$ Email of corresponding author: odedesimeon@yahoo.com
}

Technical Education Department, School of Vocational And Technical Education, Osun State College of Education, P.M.B 207, Ila-Orangun, Osun State, Nigeria

\begin{abstract}
Tracer study can provide relevant and reliable feedback on an institutions' performance in delivering quality instruction and services to its students. This cross sectional survey research of descriptive type assessed the alumni current employment status and graduates retrospective assessment of the study resources and conditions. It also investigated the relevance of knowledge and skills acquired while in school to their employment and general satisfaction with some characteristics of their job. A total of 109 technical education (TE) graduates who graduated between 2011 and 2015 were involved in the study. A modified survey questionnaire served as the main tools for data gathering. The data collected was treated using descriptive and inferential statistics. The results revealed clearly the picture of male dominance over female in terms of students' enrolment into TE Department. The findings revealed that the academic programme of TE Department is quite relevant to graduates current employment. Consequently, it was recommended among others that the college authority should try to improve the facilities in line with the explosion in number of students being admitted. Government should try as much as possible to create more jobs to enhance the employment opportunities of more graduates to reduce graduates' unemployment. The study therefore concludes that the technical education programme offered by the college is good, adequate and relevant to the needs of the students.
\end{abstract}

Keywords: Tracer study, Technical Education, Higher education, graduates survey, employment status, retrospective assessment.

\subsection{INTRODUCTION}

The role of higher institutions cannot be limited to imparting knowledge, but also to contribute to maintain a competitive economy and most important of all, to secure the dream of graduates to get jobs and become socially recognized and successful in their respective field of endeavours (Menez, 2014). According to National Policy on Education, Technical and vocational education constitutes that aspect of education and training that bothers on the acquisition of practical skills as well as basic scientific knowledge, which are vital to the improvement of man's materials beings [Federal Republic of Nigeria, (FRN) 2013]. In recognition of the role played by technical and vocational education (TVE) in supplying essential skilled manpower for the industries, the Federal Government of Nigeria included the TVE in National Policy on Education of 1979, a guideline which introduced the 6-3-3-4 now 9-3-4 system of 
education to replace the earlier 6-5-2-3 system. The policy made provisions for TVE at the secondary and tertiary levels of Nigeria's educational institutions.

One of the challenges of the implementation of the 6-3-3-4 educational policy is the provision of adequate and qualified technical teachers who would teach technical and vocational subjects in the schools. This was based on the fact that the success of any educational programme depends on the availability of adequately trained and qualified number of professional teachers, who are committed and efficient in teaching and learning process. This is in line with the provision of National Policy on Education (FRN, 2013) which stated that no education system can rise above the quality of its teachers.

In recognition of the role of technical teacher in the successful implementation of technical and vocational education programme and the quest to increase technical teacher production in Nigeria, the Osun State College of Education Ila-Orangun in 1982 established the school of technical education (TE) in her programme in preparation for the provision for technically oriented students for the 6-3-3-4 educational policy (OSSCE, 2014). The philosophy of the NCE (Technical) programme is to provide technical teachers with the intellectual and professional background adequate for teaching technical subjects and to make them adaptable to any changing situation in technological development not only in the country but also in the world at large (National Commission for Colleges of Education (NCCE), 2014). The programme was designed among others to:

- "produce qualified technical teachers and practitioners of technology capable of teaching Basic Technology in the Junior Secondary schools

- produce Technical NCE teachers who will be able to inculcate scientific and technical attitudes and values into the society.

- produce qualified technical teachers motivated to start the so much desired revolution of technological development right from Nigerian schools.

- prepare technical teachers so as to qualify them for a POST-NCE degree programme in technical education" (NCCE, 2014).

The programme also expects that students should be able to demonstrate resourcefulness in their approach to teaching and learning in the use of technological skills in the design and construction of improvised instructional apparatus using locally available materials [Technical Education, (TE), 2010]. The Technical Education department of the Osun State College of Education Ila-Orangun had graduated over 1000 students as at 2015 since it was established in the year 1982 in five major options of Automobile Technology, Building Technology, Electrical and Electronics Technology, Metalwork Technology, and Woodwork Technology. These graduates are now working in different places all over the country. However, for more than four decades of existence, no research was made to track down the TE education graduates of Osun State College of Education Ila-Orangun. In a bid to address this, there is need to conduct tracer study (TS) to determine the employability of graduates based on their retrospective assessment of what they experience while in school. Against this backdrop it is necessary to undertake a study to ascertain; what happened to former graduates of TE, what influences the department may have had upon them, occupational difficulty they had in obtaining and keeping their job and the relevance of TE graduates' knowledge and skills to their employment. This study therefore, intends to conduct a tracer/follow up study of TE programme graduates of OSSCE Ila-Orangun, Nigeria.

\subsection{Purpose of the study}

This study aimed to gather information on the transition process of the OSSCE TE graduates to work; shed light on the course of employment and work over few years period after graduation; analyse the relationships between higher education and work. Specifically, it intended to attain the following 
specific objectives: 1) to determine the profile -gender, year of graduation and area of specialization of the respondents; 2) to assess the TE graduates' current employment status and work; 3) to assess TE graduates' rating of study resources (human and material) and conditions; 4) to investigate the relevance of TE graduates' knowledge and skills to their employment.; and 5) to evaluate the extent are TE graduates satisfied with some characteristics of their jobs.

\subsection{Research Questions}

The study provides answers to the following research questions.

i. What are the TE graduates' profiles in terms of gender, year of graduation and area of specialization?

ii. What is the TE graduates' current employment status and work?

iii. How do TE graduates rate study provisions and conditions in OSSCE Ila-Orangun Osun State Nigeria?

iv. How relevant are TE graduates' knowledge and skills to their employment?

v. To what extent are TE graduates satisfied with some characteristics of their jobs?

\section{$1.3 \quad$ Research Hypotheses}

The following null hypotheses were formulated to guide the study and were tested at .05 level of significance.

$H o_{1}$ : Graduates of TE do not differ significantly in their mean rating of study provisions and conditions in OSSCE Ila-Orangun Nigeria.

$\mathrm{Ho}_{2}$ : Graduates of TE do not differ significantly in their mean responses to the relevance of knowledge and skills to their employment.

$\mathrm{Ho}_{5}$ : Graduates of TE do not differ significantly in their mean responses to the extent to which they are satisfied with some characteristics of their jobs.

\subsection{LITERATURE REVIEW}

Tracer studies or follow-up studies are essential for tertiary institutions as they are designed to find a group of individuals who have shared a specific type of training or educational background. They thus provide a basis to explore the impact of a common training or educational experience on labour market outcomes, and facilitate the collection of richer and more detailed information than generally provided in conventional household or labour force surveys (Rojas \& Rojas, 2016; Evangelista \& Morales, 2017). Undoubtedly, tracer study results is a powerful tool which documented the employment characteristics, transition to employment and the level of satisfaction of the in terms of the level of satisfaction of the higher institutions services, learning environment and facilities. It also looked into the skills and competencies of the different bachelors' degree programs in teacher education provided during the pre-service training if these existing programs were still effective, adequate and relevant in responding to the rapid and complex changes as brought about by emerging developments (Schomburg, 2003: .

Association of African Universities (AAU) in Noko and Ngulube (2013) assert that feedback from tracer studies assists educational institutions to:

"validate the achievement of training and education relating to the graduates, labour

market and employers; expose possible shortfalls in a given educational programme;

make it possible to create a network of alumni that could be helpful for knowledge 


\begin{abstract}
sharing and knowledge about possible job opportunities for current students; raise awareness of the necessary skills, knowledge and attitudes that are relevant to industry; determine the perception of an education programme by its graduates; assess the career outcomes of the graduates; provide a basis for planning future activities; and review and revise the curricula such that academic programmes might be brought more closely into line with the needs of the industry in question."
\end{abstract}

Tracer study is one way of evaluating curricular programmes, especially in higher education institutions (Ugwounah \& Omeje, 1998; Rogayana, 2019; Mancao, 2010; Gines, 2014; Ramirez, Cruz \& Alcantara, 2014; and Pannogan \& Ocampo, 2016). Therefore, it is important for the Technical Education department of the Osun State College of Education (OSSCE) Ila-Orangun, Osun State Nigeria to have a formal means of attaining feedback from its graduates through mechanisms such as tracer studies. Despite the importance of tracer studies underlined in the foregoing statements, many academic institutions in Nigeria do not make follow-up studies on their graduates a hallmark of their strategic operations. This statement still rings true today, considering the limited number of such studies in the literature in general, and technical education (TE) in particular. Few examples of such study in Nigeria are Omoifo, Badmus \& Awanbor (1998) conducted a follow-up study on Education and achievement in the early career of the University of Benin graduates. Anyanwu (2000) conducted a Graduates' Transition from Study to Employment: A Study of the Arts and Agriculture Graduates of University of Nigeria in the World of Work, and Ezeani \& Olisa (2002) conducted a study on the relevance of library science education in Nigerian universities to the world of work.

However, since the establishment of the Technical Education department of Osun State College of Education Ila-Orangun no study has been done to find out the extent to which the knowledge acquired during study programme is used in the job place, likewise no database or record of its graduates' whereabouts after graduation. This makes it difficult for the department to know where its graduates are, what they do, their employment status and how graduates got their job, the usefulness of the training received while in school and the work done and also their job satisfaction in order to make TE relevant, and make graduates support possible. It also makes it difficult to create a network of its graduates that could be helpful for knowledge sharing and knowledge about possible employment opportunities for the current students. The absence of such information denies the department valuable feedback from graduates about the value of the programme offered by the department, and makes it difficult to restructure the curriculum for current students in order for them to acquire the knowledge and skills required in the world of work. The current tracer study partly assisted in yielding such information. This study therefore, is a tracer study of Technical Education programme graduates of OSSCE Ila-Orangun Osun State, Nigeria, from 2011-2015.

\title{
3.0 METHODOLOGY
}

This study adopted a cross-sectional survey research design using quantitative methodology. Cross-sectional surveys are primarily used to determine prevalence, infer causation and also used to look for associations between observed properties, such as income level versus years of graduation based on geographic location (Mann, 2003). Only one group is used, data are collected only once and multiple outcomes can be studied; thus, this type of survey is appropriate for tracer study (Ocholla \& Shongwe, 2011). All 252 graduates of Technical Education of Osun State College of Education, Ila-Orangun who graduated between 2011 and 2015 in the five options (see Table 1) constituted the population of this study. 
Table 1: Distribution of Respondents by Year of Graduation.

\begin{tabular}{ccc}
\hline $\mathrm{S} / \mathrm{N}$ & Year of Graduation & Number of Graduates \\
\hline 1. & 2011 & 38 \\
2. & 2012 & 29 \\
3. & 2013 & 57 \\
4. & 2014 & 73 \\
5. & 2015 & 55 \\
\hline & Total & 252
\end{tabular}

(Source: Examination \& Record Office School of Vocational and Technical Education August, 2018)

\subsection{Sampling and sample techniques}

The sample for the study consist of alumni of Technical Education programme who graduated during the period under study and for whom names, addresses, e-mail and phone numbers were available in their respective files (enrolment records maintained by the department) were included in the sample. The snowballing/chain sampling approach was used this is because it is an approach particularly for difficult-to-get population. In this technique, a small number of known members of the target population were asked to introduce the researchers to other members (Adeleke, 2010). In this case, the respondents identified were asked to assist in identifying their former colleagues. In particular, they were asked if they know anybody else who graduated from Technical Education Department and where that person could be found. The information provided was used to locate and identify other graduates within the same cohort.

\subsection{Data collection tools}

The instrument used for data collection is a questionnaire adapted from Graduate and Employer Survey (Schomburg, 2003). Few items were restructured to suit the survey environment and study objectives. A bulk SMS was sent to the entire respondents via alumni e-mail and phone numbers to request for their location. Having received their responses, the researchers visited the respondents in their various organizations to administer the questionnaire directly to them and the instrument retrieved immediately after completion from respondents, where this is not possible the researchers fixed another appointment date with the concerned respondent in which the researcher will come back to retrieve the instrument.

\subsection{Data analysis}

The data collected was analysed using descriptive statistics of Frequency Count, Percentages, Rank Ordering, Mean and Standard Deviation for data derived from Likert styled questions. Standard (Linear) Multiple Regression was used to analyse the data for significant influence between a set of independent (predictors) variables and a dependent (criterion) variable in Hypothesis one, while One-way analysis of variance (ANOVA) was used to analyse the data for significant differences in Hypotheses two to five. Data was analysed using the Statistical Package for Social Sciences (SPSS version 20) programme. To determine the acceptance and rejection of mean, the mean score of 2.50 was chosen. The resulting mean score was interpreted relatively to the rating scale adopted for the study. Therefore, any item with mean response of 2.50 and above was regarded as accepted and any item with score below 2.50 was considered not accepted. To determine the decision for rejection or not rejection of the hypotheses, the cut-off point of $\mathrm{P}=0.05$ level of confidence was used as the criterion for statistical significance. 


\subsection{Graduates' profiles}

The result show that out of 109 respondents, 106 (97.2\%) were male and 3 (2.8\%) were female. This revealed that both sexes are not equally represented in the study. This is an indication that the number of female that enrolled in Technical Education is few. The result is an indication that gender disparity still abound in technical education (table 2). Likewise $19(17.4 \%)$ of the respondents graduated in 2011, $13(11.9 \%)$ graduated in 2012, 23 (21.1\%) graduated in 2013, 33 (30.3\%) graduated in 2014 and $21(19.3 \%)$ graduated in 2015 . The result show that all the graduates are almost equally represented in the sample (table 3). Results in table 4 show that, $26(23.9 \%)$ of all the respondents specialized in Automobile Technology option, 18 (16.5\%) studied Building Technology option, a whopping of 45 (41.3\%) specialized in Electrical /Electronic Technology option, 15 (13.8\%) studied Metalwork Technology option and $5(4.6 \%)$ opted for Woodwork Technology option. The result revealed that graduates in the area of woodwork technology are underrepresented compared to other options while the enrolment of students into electrical/electronic option is higher than other options in this study.

Table 2: Graduates' Gender

\begin{tabular}{lcc}
\hline Gender & Frequency & Percent (\%) \\
Male & 106 & 97.2 \\
Female & 3 & 2.8 \\
Total & 109 & 100 \\
\hline
\end{tabular}

.Table 3: Year of Graduation of the Graduates

\begin{tabular}{lll}
\hline Year of Graduation & Frequency & Percent (\%) \\
2011 & 19 & 17.4 \\
2012 & 13 & 11.9 \\
2013 & 23 & 21.1 \\
2014 & 33 & 30.3 \\
2015 & 21 & 19.3 \\
Total & $\mathbf{1 0 9}$ & $\mathbf{1 0 0}$ \\
\hline
\end{tabular}

Table 4: Area of Specialization

\begin{tabular}{lll}
\hline Area of Specialization & Frequency & Percent (\%) \\
Automobile Technology & 26 & 23.9 \\
Building Technology & 18 & 16.5 \\
Electrical and Electronic Technology & 45 & 41.3 \\
Metalwork Technology & 15 & 13.8 \\
Woodwork Technology & 5 & 4.6 \\
Total & $\mathbf{1 0 9}$ & $\mathbf{1 0 0 . 0}$ \\
\hline
\end{tabular}

\subsection{Graduates' current Employment Rate and Status}

From Table 5, 85 (78\%) of the respondents were employed, 3 (2.8\%) were self-employed, while $21(19.3 \%)$ were not employed. In addition the result further shows that $82(75.1 \%)$ were permanently employed, 4 (3.7\%) were employed temporarily, while 23 (21.2\%) did not indicated the nature of their employment (Table 6). From this result it is evident that the majority of the respondents are employed permanently. Furthermore, the findings shows that out of 109 respondents $88(80.7 \%)$ were employed in public sector, $4(3.7 \%)$ were employed in private sector, $3(2.8 \%)$ were self-employment while 14 $(12.8 \%)$ gave no response (Table 7). The result revealed that public sector remains the viable means of 
guarantee jobs for TE graduates. With regard to the economic sector where graduates were employed, the result from the table 8 show that $80(73.4 \%)$ of the respondents were employed in secondary/vocational technical schools, $9(8.3 \%)$ were employed in tertiary institution, $1(0.9 \%)$ were employed in industry while $14(12.8 \%)$ were employed in other sector which may be self-employed. The result is an indication that the majority of the respondents are engaging in teaching profession. This means, the schools both secondary/technical/vocational institutions as a public sector is the major employment sector that requires the skills obtained in Nigeria certificate in Education (technical education).

Table 5: Employment Status the of Graduates

\begin{tabular}{lll}
\hline Employment status & Frequency & Percent (\%) \\
\hline Employed & 85 & 78 \\
Self-employed & 3 & 2.8 \\
Not employed & 21 & 19.3 \\
Total & $\mathbf{1 0 9}$ & $\mathbf{1 0 0 . 0}$ \\
\hline
\end{tabular}

Table 6: Nature of Employment of the Graduates

\begin{tabular}{lll}
\hline Nature of Employment & Frequency & Percent $(\%)$ \\
\hline No response & 23 & 21.2 \\
Permanent & 82 & 75.2 \\
Temporary & 4 & 3.7 \\
Total & 109 & 100.0 \\
\hline
\end{tabular}

Table 7: Type of Employers of graduates

\begin{tabular}{lll}
\hline Kind of Employers & Frequency & Percent (\%) \\
\hline No response & 14 & 12.8 \\
Public & 88 & 80.7 \\
Private & 4 & 3.7 \\
Self-employed & 3 & 2.8 \\
Total & $\mathbf{1 0 9}$ & $\mathbf{1 0 0 . 0}$ \\
\hline
\end{tabular}

Table 8: Economic Sector of Graduates

\begin{tabular}{lll}
\hline Economic sector & Frequency & Percent $(\%)$ \\
Secondary/ technical college & $\mathbf{8 0}$ & $\mathbf{7 3 . 4}$ \\
Tertiary institution & $\mathbf{9}$ & $\mathbf{8 . 3}$ \\
Industry & 1 & $\mathbf{0 . 9}$ \\
Others & $\mathbf{5}$ & $\mathbf{4 . 6}$ \\
No response & $\mathbf{1 4}$ & $\mathbf{1 2 . 8}$ \\
Total & $\mathbf{1 0 9}$ & $\mathbf{1 0 0 . 0}$ \\
\hline
\end{tabular}

\subsection{Graduates rating of study resources (human and material) and conditions in TE Department.}

Respondents were asked to rate study resources (human and material) and conditions in TE Department, 24 items were provided to the respondents in order to express their opinions. The respondents rated the 15 items on study provisions and conditions good, while the remaining 9 items was rated poor (Table 9). 
Table 9: Mean of Responses on the Graduates' ratings of Study Resources (human and material) and Conditions in the Department

\begin{tabular}{|c|c|c|c|c|c|c|c|c|}
\hline & & \multicolumn{7}{|c|}{$N_{1}=19, N_{2}=13, N_{\mathrm{a}}=23, N_{4}=33, N_{5}=21, N_{\mathrm{t}}=109$} \\
\hline $\mathbf{S} / \mathbf{N}$ & ITEMS & $\overline{\bar{x}_{1}}$ & $\overline{\mathrm{X}}_{2}$ & $\overline{\mathrm{X}_{3}}$ & $\overline{\mathrm{X}}_{4}$ & $\overline{\mathrm{X}}_{5}$ & $\overline{X_{t}}$ & Remark \\
\hline 1 & Teaching practice & 3.42 & 3.23 & 3.35 & 3.21 & 3.52 & 3.34 & Good \\
\hline 2 & Teaching quality of lecturers & 3.21 & 3.23 & 3.39 & 3.12 & 3.33 & 3.35 & Good \\
\hline 3 & $\begin{array}{l}\text { Provision of supervision for Teaching } \\
\text { Practice }\end{array}$ & 3.11 & 2.77 & 2.61 & 2.91 & 3.19 & 2.92 & Good \\
\hline 4 & Adequacy of teaching staff & 3.21 & 3.52 & 3.30 & 3.09 & 3.00 & 3.19 & Good \\
\hline 5 & Structure of degree programme & 3.11 & 3.31 & 3.26 & 3.00 & 3.38 & 3.18 & Good \\
\hline 6 & Scope \& coverage of courses & 3.32 & 3.54 & 3.43 & 3.21 & 3.24 & 3.32 & Good \\
\hline 7 & Games / Recreation facilities & 1.53 & 1.46 & 1.57 & 1.52 & 1.57 & 1.53 & Poor \\
\hline 8 & Testing/Grading System in examinations & 3.05 & 3.05 & 3.23 & 3.13 & 3.03 & 3.29 & Good \\
\hline 9 & Opportunities for co-curricular activities & 3.00 & 3.08 & 3.00 & 2.67 & 2.67 & 2.83 & Good \\
\hline 10 & Quality of administration & 2.79 & 3.00 & 2.78 & 2.94 & 2.48 & 2.80 & Good \\
\hline 11 & Equipment \& stocking of library & 1.53 & 1.54 & 1.48 & 1.61 & 1.33 & 1.50 & Poor \\
\hline 12 & Accommodation facilities on campus & 1.63 & 1.54 & 1.61 & 1.55 & 1.76 & 1.61 & Poor \\
\hline 13 & Quality of buildings & 2.68 & 3.08 & 2.74 & 2.92 & 3.00 & 2.89 & Good \\
\hline 14 & Counselling services & 1.37 & 1.62 & 1.48 & 1.45 & 1.62 & 1.50 & Poor \\
\hline 15 & Assistance/advice for examination & 2.53 & 2.54 & 2.52 & 2.76 & 2.62 & 2.61 & Good \\
\hline 16 & Academic advice offered & 2.79 & 2.92 & 2.87 & 2.91 & 2.67 & 2.83 & Good \\
\hline 17 & Quality of equipment in labs/workshops & 1.42 & 1.15 & 1.35 & 1.52 & 1.48 & 1.41 & Poor \\
\hline 18 & Supply of learning materials & 1.95 & 1.54 & 1.65 & 1.76 & 1.71 & 1.73 & Poor \\
\hline 19 & Availability of technical equipment & 1.84 & 2.00 & 1.91 & 1.79 & 1.81 & 1.85 & Poor \\
\hline 20 & Research projects & 2.79 & 3.08 & 2.70 & 2.79 & 2.62 & 2.77 & Good \\
\hline 21 & $\begin{array}{l}\text { Possibility of individual structuring of } \\
\text { studies }\end{array}$ & 2.68 & 3.23 & 3.09 & 2.70 & 3.14 & 2.93 & Good \\
\hline 22 & $\begin{array}{l}\text { Opportunity for out of class contacts } \\
\text { with teaching staff }\end{array}$ & 3.00 & 3.00 & 2.96 & 2.91 & 2.52 & 2.87 & Good \\
\hline 23 & $\begin{array}{l}\text { Chance for students to influence college } \\
\text { policy }\end{array}$ & 1.74 & 1.46 & 1.74 & 1.82 & 1.62 & 1.71 & Poor \\
\hline 24 & Balance between theory and practical & 1.26 & 2.15 & 1.78 & 1.79 & 1.62 & 1.71 & Poor \\
\hline
\end{tabular}

Table 10: One Way Analysis of Variance (ANOVA) of the Graduates of TE mean ratings of study provisions and conditions

\begin{tabular}{llllll}
\hline Source & Sum of Squares & $d f$ & Mean Square & F & Sig. \\
\hline Between Groups & $\mathbf{1 4 3 . 0 3 6}$ & & & & \\
Within Groups & 5097.973 & 104 & 49.019 & .729 & $.574 *$ \\
Total & 5241.009 & 108 & & & \\
\hline
\end{tabular}

* Not significant at 0.05 alpha level

Table 10 shows that $\mathrm{F}(4,104)=0.729, \mathrm{P}>0.05$. The result revealed that there is no significant different in the mean ratings of graduates (2011-2015) on the study provisions and conditions experienced while in the College. Thus the null hypothesis is not rejected. 


\subsection{Relevance of the knowledge and skills acquired to the graduates' employment}

One of the objectives of this study was to ascertain if the skills and knowledge the graduates had acquired from their education and training were relevant to their employment. The data presented in Table 11 displays the responses of the graduates on the skills and knowledge they acquired, the respondents rated the 26 items relevant to the knowledge and skills they acquired in school to their current job while the remaining 1 item on research project was rated not relevant. This is an indication that courses offered in the Technical Education are relevant and beneficial to the graduates in their employment.

Table 11: Mean of Responses on the Relevance of Knowledge and Skills Acquired to Current Job.

\begin{tabular}{|c|c|c|c|c|c|c|c|c|}
\hline & & & $N_{1}=$ & $\mathrm{N}_{2}=$ &,$N_{a}=$ & $N_{4}=$ & $3, N_{5}=$ & $1, N_{t}=109$ \\
\hline $\mathbf{S} / \mathbf{N}$ & ITEMS & $\bar{X}_{1}$ & $\overline{\mathrm{x}}_{2}$ & $\overline{\mathrm{X}}_{3}$ & $\overline{\mathrm{X}}_{4}$ & $\overline{\mathrm{X}} 5$ & $\overline{\mathrm{X}} \mathbf{t}$ & Remark \\
\hline 1 & Knowledge of English & 3.53 & 3.62 & 3.26 & 3.36 & 2.38 & 3.21 & Relevant \\
\hline 2 & SIWES & 3.21 & 3.23 & 3.30 & 3.21 & 2.29 & 3.06 & Relevant \\
\hline 3 & Teaching practice & 3.58 & 3.54 & 3.48 & 3.24 & 2.43 & 3.23 & Relevant \\
\hline 4 & Workshop practice & 3.42 & 3.08 & 3.43 & 3.15 & 2.19 & 3.06 & Relevant \\
\hline 5 & Mathematics (Algebra, Calculus) & 3.11 & 3.46 & 3.13 & 3.27 & 2.33 & 3.06 & Relevant \\
\hline 6 & Computer & 3.16 & 3.38 & 3.52 & 3.12 & 1.95 & 3.02 & Relevant \\
\hline 7. & $\begin{array}{l}\text { Natural sciences } \quad \text { (Physics, } \\
\text { Chemistry) }\end{array}$ & 2.74 & 3.15 & 2.96 & 2.88 & 1.76 & 2.69 & Relevant \\
\hline 8. & General studies & 2.95 & 3.15 & 3.04 & 2.88 & 2.05 & 2.80 & Relevant \\
\hline 9. & Research project & 1.89 & 1.31 & 1.70 & 2.27 & 1.67 & 1.85 & $\begin{array}{l}\text { Not } \\
\text { Relevant }\end{array}$ \\
\hline 10. & $\begin{array}{l}\text { Major Technology courses e.g } \\
\text { Auto, Building, Metal, Elect/Elect, } \\
\text { and Woodwork }\end{array}$ & 3.84 & 3.92 & 3.74 & 3.73 & 2.48 & 3.53 & Relevant \\
\hline 11. & $\begin{array}{l}\text { Engineering (Building and } \\
\text { Mechanical) drawing }\end{array}$ & 3.32 & 3.38 & 3.52 & 3.06 & 2.19 & 3.07 & Relevant \\
\hline 12. & Technical drawing & 3.32 & 3.31 & 3.52 & 3.03 & 2.24 & 3.06 & Relevant \\
\hline 13. & Graphics & 3.05 & 3.38 & 3.61 & 3.00 & 2.19 & 3.03 & Relevant \\
\hline 14. & Special Methodology & 3.26 & 3.38 & 3.43 & 2.97 & 2.33 & 3.05 & Relevant \\
\hline 15. & $\begin{array}{l}\text { Entrepreneurship in technical } \\
\text { education }\end{array}$ & 2.37 & 2.92 & 3.09 & 2.91 & 2.05 & 2.69 & Relevant \\
\hline 16. & $\begin{array}{l}\text { Introduction to Vocational and } \\
\text { Technical Education }\end{array}$ & 2.58 & 3.23 & 3.26 & 3.03 & 2.19 & 2.86 & Relevant \\
\hline 17. & $\begin{array}{l}\text { Material technology } \\
\text { Applied Mechanics) }\end{array}$ & 2.84 & 3.38 & 3.30 & 3.00 & 2.14 & 2.92 & Relevant \\
\hline 18. & Maintenance and Repairs & 2.58 & 3.00 & 3.09 & 3.15 & 2.10 & 2.82 & Relevant \\
\hline 19. & $\begin{array}{l}\text { Research method and } \\
\text { processing }\end{array}$ & 2.95 & 3.15 & 2.87 & 3.00 & 2.14 & 2.82 & Relevant \\
\hline 20. & $\begin{array}{l}\text { Educational administration and } \\
\text { planning }\end{array}$ & 3.11 & 3.38 & 3.35 & 3.12 & 2.38 & 3.06 & Relevant \\
\hline 21. & Measurement and evaluation & 2.84 & 3.38 & 3.39 & 2.97 & 2.33 & 2.96 & Relevant \\
\hline 22. & Curriculum studies & 2.95 & 3.31 & 3.13 & 3.00 & 2.14 & 2.89 & Relevant \\
\hline 23. & Micro teaching & 2.89 & 3.15 & 3.17 & 2.97 & 2.33 & 2.90 & Relevant \\
\hline 24. & Educational Technology & 2.79 & 3.00 & 3.30 & 3.12 & 2.29 & 2.93 & Relevant \\
\hline
\end{tabular}




\begin{tabular}{lllllllll}
\hline 25. & School Workshop management & 2.79 & 3.38 & 3.35 & 3.06 & 2.19 & 2.94 & Relevant \\
26. & Educational Psychology & 2.79 & 3.15 & 3.17 & 2.91 & 2.29 & 2.85 & Relevant \\
27. & Philosophy of Education & 2.79 & 2.77 & 2.96 & 2.96 & 2.00 & 2.66 & Relevant \\
\hline
\end{tabular}

Table 12: One Way Analysis of Variance (ANOVA) of the Graduates of TE 2011-2015 mean responses on the relevance of the knowledge and skills acquired in school to their employment.

\begin{tabular}{llllll}
\hline Source & Sum of Squares & df & Mean Square & F & Sig. \\
Between Groups & 11807.583 & 4 & 2951.896 & 5.508 & $.000^{*}$ \\
Within Groups & 55740.270 & 104 & 535.964 & & \\
Total & 67547.853 & 108 & & &
\end{tabular}

*Significant

The result of the analysis presented in Table 12 show that $\mathrm{F}(4,104)=5.508, \mathrm{p}<0.05$. The mean and standard deviation of the graduates 2011 were 83.68 and 8.98, 2012 were 89.5 and 9.27, 2013 were 90.5 and 7.94, 2014 were 85.18 and 17.87 and 2015 were 81.96 and 25.0 respectively. This result revealed that there is statistically significant difference in the mean responses of the graduates on the relevance of the knowledge and skills acquired in the school to their employment. Thus the null hypothesis is rejected. Further verification of the groups of graduates that constitute the difference is shown in the post-hoc test. The result of the post-hoc test (TURKEY HSD) indicated that mean responses of graduates of 2015 is statistically differed from the mean responses of graduates of 2011, 2012, 2013 and 2014. This indicated that it is the graduates of 2015 that constitute the difference in the responses on the relevance of the knowledge and skills acquired to their employment.

\subsection{Graduates satisfaction with some characteristics of their job}

The data presented in Table 13 shows that the respondents rated the 8 items to high extent their level of satisfaction with some characteristics of their job while the remaining 6 items were rated to a low extent. From the results it is evident that most of the respondents were satisfied with eight characteristics. Overall, result indicated that $70(54.2 \%)$ of the respondents were satisfied with their job, while 27 $(24.7 \%)$ were not satisfied (Table 14$)$. This result was rather not surprising considering that majority of NCE Technical graduates are in teaching profession. On the whole these results indicate that the respondents were satisfied with their job.

Table 15 shows the ratings of respondents on how important certain occupational characteristics are to them. The result shows that job security was ranked first with the mean score of 3.89. This indicated that the most important characteristic was job security. High income was ranked $2^{\text {nd }}$ with mean score of 3.76 followed by possibility of using acquired knowledge and good career prospects which was ranked $3^{\text {rd }}$ and $4^{\text {th }}$ with mean score of 3.46 and 3.28 respectively. Good working atmosphere and opportunity of pursuing continuous learning has the same mean scores of 3.23 and was ranked fifth $\left(5^{\text {th }}\right)$. Chance of doing something useful for the society was ranked $7^{\text {th }}$ with mean score of 3.20 . Possibility of working in a team, social status and respect, opportunity of pursuing own ideas, largely independent disposition of work, coordinating and management tasks and demanding job tasks with mean scores of $3.10,3.09,3.03,2.93,2.91$ and 2.85 was ranked $9^{\text {th }}, 10^{\text {th }}, 11^{\text {th }}, 12^{\text {th }}, 13^{\text {th }}$ and $14^{\text {th }}$ respectively. In contrast lot of free time and chances of political influence with mean scores of 2.56 and was ranked $15^{\text {th }}$ and $16^{\text {th }}$ respectively. 
Table 13: The Extent to which TE Graduates are Satisfied with some Characteristics of their Job.

\begin{tabular}{llccccccc} 
& \multicolumn{6}{c}{$N_{1}=19, N_{2}=13, N_{\mathrm{a}}=23, N_{4}=33, N_{5}=21, N_{\mathrm{t}}=109$} \\
\hline $\mathbf{S} / \mathbf{N}$ & ITEMS & $\overline{\mathrm{X}}_{\mathbf{1}}$ & $\overline{\mathrm{X}}_{\mathbf{2}}$ & $\overline{\mathrm{X}}_{\mathbf{3}}$ & $\overline{\mathrm{X}}_{\mathbf{4}}$ & $\overline{\mathrm{X}}_{\mathbf{5}}$ & $\overline{\mathrm{X}}_{\mathrm{t}}$ & Remark \\
\hline $\mathbf{1}$ & Job security & 2.84 & 3.46 & 3.17 & 2.76 & 2.05 & 2.81 & High Extent \\
$\mathbf{2}$ & Possibility to use qualifications acquired & 2.89 & 3.08 & 2.87 & 2.42 & 1.90 & 2.58 & High Extent \\
& during my studies & & & & & & & \\
$\mathbf{3}$ & Content of work/the professional tasks & 2.95 & 3.15 & 2.83 & 2.45 & 1.90 & 2.60 & High Extent \\
$\mathbf{4}$ & Opportunity to benefit society & 3.05 & 2.92 & 3.04 & 2.48 & 1.90 & 2.64 & High Extent \\
$\mathbf{5}$ & Possibility to work in a demanding job & 3.05 & 3.38 & 3.30 & 2.42 & 1.76 & 2.71 & High Extent \\
$\mathbf{6}$ & Work environment & 2.95 & 3.31 & 3.04 & 2.00 & 1.71 & 2.49 & Low Extent \\
$\mathbf{7}$ & Equal treatment of all employees & 2.63 & 2.69 & 2.61 & 2.36 & 1.86 & 2.40 & Low Extent \\
$\mathbf{8}$ & Chance of realizing own ideas & 3.11 & 3.00 & 3.13 & 2.25 & 1.95 & 2.68 & High Extent \\
$\mathbf{9}$ & Opportunity for further studies & 3.16 & 3.31 & 3.00 & 2.33 & 1.86 & 2.64 & High Extent \\
$\mathbf{1 0}$ & Position achieved & 2.95 & 3.46 & 3.26 & 2.52 & 2.05 & 2.77 & High Extent \\
$\mathbf{1 1}$ & Promotion prospects & 2.63 & 3.08 & 2.48 & 2.27 & 1.90 & 2.40 & Low Extent \\
$\mathbf{1 2}$ & Equipment of workplace & 2.58 & 3.15 & 2.87 & 2.33 & 1.76 & 2.48 & Low Extent \\
$\mathbf{1 3}$ & Income & 2.26 & 2.46 & 2.43 & 2.03 & 1.81 & 2.17 & Low Extent \\
$\mathbf{1 4}$ & Fringe benefits & 2.32 & 2.62 & 2.52 & 2.06 & 1.71 & 2.20 & Low Extent \\
\hline
\end{tabular}

Table 14: General Satisfaction of Graduates with Different Characteristics of Job.

\begin{tabular}{lll}
\hline General job satisfaction & Frequency & Percent (\%) \\
\hline No response & 12 & 11.0 \\
Not at all & 2 & 1.8 \\
Low extent & 25 & 22.9 \\
High extent & 50 & 45.9 \\
Very high extent & 20 & 18.3 \\
Total & $\mathbf{1 0 9}$ & $\mathbf{1 0 0 . 0}$ \\
\hline
\end{tabular}

Table 15: Importance of Different Characteristics of an Occupation to the Graduates

\begin{tabular}{llll}
\hline $\mathbf{S} / \mathbf{N}$ & ITEMS & Mean $(\overline{\mathbf{X}} \mathbf{t})$ & Remarks \\
\hline $\mathbf{1}$ & Job security & 3.89 & $1^{\text {st }}$ \\
$\mathbf{2}$ & Possibilities of using acquired knowledge & 3.46 & $3^{\text {td }}$ \\
$\mathbf{3}$ & Chances of doing something useful for the society & 3.20 & $7^{\text {th }}$ \\
$\mathbf{4}$ & Good working atmosphere & 3.23 & $5^{\text {th }}$ \\
$\mathbf{5}$ & Possibility of working in a team & 3.16 & $8^{\text {th }}$ \\
$\mathbf{6}$ & Social status and respect & 3.10 & $9^{\text {th }}$ \\
$\mathbf{7}$ & Opportunity of pursuing own ideas & 3.09 & $10^{\text {th }}$ \\
$\mathbf{8}$ & Good career prospects & 3.28 & $4^{\text {th }}$ \\
$\mathbf{9}$ & Opportunity of pursuing continuous learning & 3.23 & $5^{\text {th }}$ \\
$\mathbf{1 0}$ & High income & 3.76 & $2^{\text {th }}$ \\
$\mathbf{1 1}$ & Largely independent disposition of work & 3.03 & $11^{\text {th }}$ \\
$\mathbf{1 2}$ & Coordinating \& management of tasks & 2.99 & $12^{\text {th }}$ \\
$\mathbf{1 3}$ & Demanding job tasks & 2.91 & $13^{\text {th }}$ \\
$\mathbf{1 4}$ & Opportunity of undertaking scientific work & 2.85 & $14^{\text {th }}$ \\
$\mathbf{1 5}$ & Lot of free time & 2.56 & $15^{\text {th }}$ \\
$\mathbf{1 6}$ & Chances of political influence & 2.48 & $16^{\text {th }}$ \\
\hline
\end{tabular}


Table 16: One Way Analysis of Variance (ANOVA) of the Graduates of ITE mean responses on the extent to which they are satisfied with some characteristics of their job

\begin{tabular}{llllll}
\hline Sources & Sum of Squares & Df & Mean Square & F & Sig. \\
Between Groups & 3680.567 & 4 & 920.142 & 4.686 & $.002^{*}$ \\
Within Groups & 20420.295 & 104 & 196.349 & & \\
Total & 24100.862 & 108 & & & \\
& & & & & \\
\hline
\end{tabular}

*significant

The result of the analysis presented in Table 16 show that $F(4,104)=4.684, p<0.05$. The mean and standard deviation of the graduates 2011 were 39.37 and 6.13, 2012 were 43.08 and 6.14, 2013 were 40.57 and 6.60, 2014 were 32.91 and 16.29 and 2015 were 26.14 and 22.18 respectively. This result revealed that there is statistically significant different in the mean responses of the graduates on the extent to which they are satisfied with some characteristics of their job. Thus the null hypothesis is rejected. Further verification of the groups of graduates that constitute the difference is shown in the post-hoc test. The result of the post-hoc test (TURKEY HSD) indicated that mean responses of graduates of 2015 is statistically differed from the mean responses of graduates of 2011, 2012, 2013 and 2014. This indicated that it is the graduates of 2015 that constitute the difference in the responses on the extent to which they are satisfied with some characteristics of their job.

\subsection{DISCUSSION}

The study found a gender disparity in Technical Education (TE) in Nigeria. It deduced that the picture of male dominance over female in terms of students' enrolment into Technical Education is clear. This result is in agreement with the finding of Odede and Adewale (2013) who averred that male student' enrolment was greater than female student's enrolment in technical colleges in all of the years of study. It is not surprising that few female had studied TE; this is because in Nigeria society technical education was viewed as being masculine. Although the study targeted graduates who had finished their studies between 2011 and 2015, the results revealed that $17.4 \%$ graduated in $2011,11.9 \%$ in $2012,21.1 \%$ in $2013,30.3 \%$ in 2014 and $19.3 \%$ graduated in 2014 .

Looking at the proportion of the graduates produced by the department from 2011 to 2015 and those that took part in this survey, the result shows that all the graduates are almost equally represented in the sample. The graduates' area of specialization is an important labour market consideration. All areas of specialization in TE are seen to be clearly vocational and this makes it easier for the graduates in these fields to move to "corresponding occupations". The findings revealed that enrolment of students into Electrical/Electronic option is much higher than other options. Also the proportion of graduates in Woodwork technology options is low.

The results showed that most (78\%) of the graduates were employed and permanently employed. Overall self employment seems to be a marginal phenomenon. Only $2.8 \%$ of the graduates were reported to be self employed. Majority of the graduates (77.1\%) were still in their entry jobs. The result are similar to the findings of Karagu and Otiende (2001) that 93\% of graduates of Kenyatta University had not changed their job which is attributed to either favourable working condition or lack of suitable alternatives. Most graduates in the employment were employed in public sector. It is evident that the government is their principal employer as those in the employment were mainly working in the schools (secondary/technical and vocational schools) and tertiary educational institution. The finding is in consonant with the findings of Dabalen, Oni and Adekola (2000) in their incisive study of labour market 
for Nigerian graduates. Dabalen et al. (2000) confirmed from manpower surveys and tracer studies that 58 and 35\% of graduate employees worked in the public sector in 1984 and 1991 respectively. However, a close study of the applications and hires into the Civil Service in Nigeria reveals a very gloomy prospect for graduate employment in Nigeria. This heritage is yet to die out as the public sector is regarded as a major employer of graduates from Technical Education Department of College of Education.

The results revealed that fifteen out of twenty four items raised on the study resources (human and material) and conditions in the department were rated good. Study resources (human and material) and conditions such as teaching practice, adequacy of teaching staff, structure of programme, scope and coverage of courses, testing and grading system in examinations, opportunities for co-curricular activities, qualities of administration, quality of building, assistance/advice for examination, academic advice offered, research projects and opportunity for out of class contacts with teaching staff were all rated good. The acceptance of these identified study resources (human and material) and provisions is an indication that the department of TE has competent, qualified and dedicated lecturers. However, games and recreation facilities, equipment and stocking of library, accommodation facilities on campus, counselling services, and quality of equipment in laboratory/workshops, supply of learning materials availability of technical equipment, chance for students to influence college policy and balance theory and practical were rated poor. Most graduates were dissatisfied with these study resources (human and material) and provisions. This is not too surprising since more students are using the facilities that initially provided.

The result is in line with Omoifo, Badmus and Awanbor (1998) that the university is only refurbishing the old facilities and equipment instead of providing new one because of the slim in the financial allocation to the institution. This no doubt has implications on the quality of graduates and consequently on their performance in the labour market. It is not surprising that these days students do not have current books to consult in the library, catering services are also poor. This finding is also agreed with the findings of Oni and Dabalen (2000) that poor quality of graduates is caused by shortage of learning resources (libraries, laboratories) and funding limitation. Many institutions libraries are reported to hold out of date collections. In particular, graduates rated balanced theory and practical very poor. This result is in agreement with the findings of Omoifo, Badmus and Awanbor (1998) that graduates of Nigerian universities rated supervised practical work and quality of academic advice received as very poor.

The result revealed that there is statistically significant difference on the relevance of knowledge and skills acquired during study programme to their current job. This is quite impressive as it indicates that the academic programme of TE department is relevant, at least the area under study. This result is in line with the view of Odu (2011b) that a curriculum is needed to facilitate the acquisition of skills and knowledge so that students may gain employment in related field. The curriculum of TE was able to provide its recipient the skills and knowledge relevant to their employment. This is an indication that the curriculum of NCE (Technical) has been able to meet the challenge of the jobs the students take up after graduation. The finding revealed that the course content of the major technology courses which are Automobile, Building, Metal, Electrical/Electronic and Woodwork Technology was considered quite relevant to their current work. These are subjects that they teach in secondary/vocational/technical schools and other related institutions. This is not surprising since the educational units taught at the department aim at grounding the graduates in the professional aspects and content delivery. On the other hand, the teaching subjects learnt aim at making teacher's competent in their teaching areas. The finding also revealed that knowledge of English Language is also relevant to the graduates' current job. This may be because English language is used as means of communication in the country. Knowledge of English language will enable the graduates communicate effectively both orally and in written. Even if the teacher is very knowledgeable in the content area, teaching cannot be effective unless he communicates effectively. 
The finding further revealed that variety of courses offered in TE department such as workshop practice, mathematics, computer, natural sciences are all relevant to graduates current job. This assessment seems justified as those courses are interrelated to major technology courses. Other major courses that graduates have recognised being relevant as revealed by the study is the entrepreneurship, since one of the objectives of the department is to train the graduates to be self reliant, knowledge of entrepreneurship will help those graduates that want to be self employed. Other relevant knowledge and skills as revealed by the findings is technical drawing, maintenance and Repairs, material technology (Fluids and Applied Mechanics), quality control, technology, school workshop organization and management. The results agreed with the findings of Anyanwu (2000) that about $70 \%$ of graduates of Arts and Agriculture of University of Nigeria rated the extent of relevant of the acquired knowledge and skills high.

The result revealed that there is statistically significant difference in their mean responses. The researcher further observed that majority of 2015 graduates is yet to secure employment. It is very difficult for them to indicate their level of satisfaction with some characteristics of their job.

The results showed that graduates satisfied with job characteristics such as job security, possibility to use qualifications acquired during their studies, content of their work/professional tasks, opportunity to benefit society, possibility to work in a demanding job, chance of realizing own ideas, opportunity for further studies and position achieved. Job security was the characteristics in which most of the graduates expressed satisfaction with in their profession. This could be because one of the important aspects of public service which include teaching profession is job security.

This is in line with the findings of Karagu and Otiende (2001) that public service is associated with job security. Once a worker has been confirmed, the job security is guarantee, unlike private sector where job security depend on performance and this is done at management will. Respondents were overwhelmingly indicated dissatisfaction with the characteristics of income they receive, fringe benefits, equal treatment of all employees. This finding further showed that the least rated aspect of the job characteristics was the fringe benefits with average mean of 1.71 . This could be due to the fact that in public service most especially teaching service, workers have very few fringe benefits. This is unlike in the private sector where employees enjoy benefits such as full medical cover, education benefit for dependants housing loan and car loan.

\subsection{Conclusion}

The study was a tracer study of TE programme graduates. The study investigated the employment status of the graduates and how some socio-demographic characteristics of the graduates had influence their employment status. The study is a retrospective assessment of the graduates on the study provisions and conditions. The study also looked at the relevance of knowledge and skill acquired while in school to their current employment.

The department of Technical Education had produced more than 1000 graduates in five major options of Automobile Technology, Building Technology, Metal work Technology, Electrical/Electronic Technology and Woodwork Technology. Majorities of this graduates end up in public sector employment where there is job security the private sector and self-employment remain less attractive. Most graduates in the teaching profession remain longer in the employment and ironically, suffer the most job dissatisfaction. Most graduates had used the knowledge and skills acquired in various course units in their employment. Furthermore, the TE graduates express concern over the pressure on facilities and the need to expand existing structures and provide more infrastructures in order to improve learning situation in the College. 
Based on the findings of this study, it is recommended that:

- The ministry of education should constantly organized seminars, workshops and conference for the students, especially female students on the role of Technical Education in economic and industrial development of the country, so as to reduce gender disparity in technical and vocational education.

- Emphasis should be placed on practical and entrepreneurial training to bridge the gap between theory and practical so that the graduates will be able to face the challenges of work in the industry if employed and be self employed and become employer of labour instead of depending solely on public sector or paid employment in this era of economic distress and unemployment.

- As majority of TE graduates worked in public sector most especially the educational sector, the requirements of the growing private sector job market need to be reflected in the TE programme so as to create more opportunities for graduates to be employed in another area where knowledge and skills acquired can be put to more creative use.

- Government should try as much as possible to create more jobs to enhance the employment opportunity of more graduates and reduce graduates' unemployment.

- An intensive curriculum review may be considered by the National Commission (NCCE) for Colleges of Education who is charged with the responsibility of monitoring and supervision of colleges of education in Nigeria to align the programme and course intended learning outcomes to the 21 st Century learning landscape.

\section{Acknowledgements} this research.

We gratefully acknowledge funding from TETFund institutional-based research intervention for

\section{References}

Adeleke, J.A (2010). The Basics of Research and Evaluation Tools. Ikeja-Lagos. Somerest Ventures.

Association for African Universities (AAU) (2002). Regional workshop on tracer studies of past university students. University of Namibia, 7-11, Retrieved from http://www.aau.org//?q1/4sphema/reports

Anyanwu, G.A. (2000). Graduates' Transition from Study to Employment: A Study of the Arts and Agriculture Graduates of University of Nigeria in the World of Work. Department of Home Science, University of Nigeria, Nsukka: 56-97

Dabalen, A. Oni, B. \&Adekoka, O. (2000). Labour Market Prospect of University Graduates in Nigeria. World Bank, Washington D.C.

Evangelista, E.V., \& Morales M.P.E. (2017). Tracing the science education graduates. International Journal of Research Studies in Education, 6(2), 69-80. https://doi.org/10.5861/ijrse.2016.1566 
Ezeani, C.N \& Olisa M.S (2002). The relevance of library science education in Nigerian universities to the world of work. Accra, Ghana, AAU. Research Report submitted to Association of African Universities

Federal Republic of Nigeria (FGN) (2013). National Policy on Education (Revised), Abuja. NERDC.

Gines, A.C. (2014). "Tracer Study of PNU Graduates" in American International Journal of Contemporary Research, Vol.4, No.3 [March]. Available online also at: http://www.aijcrnet.com/journals/4(3)_March_2014/10.pdf

Karugu, A. \& Otiende, J.E (2001). Higher education and work: Survey of graduates of Kenyatta University (1985-1995). Nairobi, Kenya: AAU research report.

Mancao, C. (2010). "A Tracer Study of the Graduates of ATEM-PLUS, Part 1" in PNU Crede Research Series, 11, 1-15.

Mann, C.J. (2003). Observational research methods. Research design II: cohort, cross sectional, and casecontrol studies. Emerg Med J 2003; 20:54-60. Retrieved from http://emj.bmj.com/content/20/1/54.full.html

Meñez, N.L. (2014). Tracer Study of the Masters in Business Administration (MBA) Graduates from 2008-2012, Asia Pacific Journal of Education, Arts and Sciences, 1(1), 14-18. Retrieved from www.apjeas.apjmr.com

National Commission for Colleges of Education (NCCE) (2014). Nigeria certificate in education minimum standards for vocational and technical education, 2012 edition. Abuja, National Commission for Colleges of Education.

Noko, P. \& Ngulube, P. (2013). A Vital Feedback Loop in Educating and Training Archival Professionals: A Tracer Study of Records and Archives Management Graduates in Zimbabwe. Information Development, 31(3) 270-283.

Ocholla D.N.\& Shongwe M (2011) A tracer study of LIS graduates at the University of Zululand, 20002009. Mousaion 29 (2): 227-245.

Odede, S.O. and Adewale, J.G (2013). ). Student intrinsic and extrinsic factors as correlates of technical and vocational enrolment in Osun State. In Learning; A Book in honour of Professor T.Y Yoloye; Mokola, Ibadan. Society for the promotion of Academic and Research Excellence (SPARE), 286-296.

Odu, O.K. (2011b) Reappraising the Work Skill Requirements for Building Technology Education in Senior Secondary School for Optimum Performance in Nigeria. Proceedings of the 1st International Technology, Education and Environment Conference (c) African Society for Scientific Research (ASSR).

Omoifo, C., Badmus, G. \& Awanbor, D. (1998). Education and achievement in the early career of the University of Benin Graduates. Report of 1996 University of Benin Graduate's Survey. Faculty of Education, University of Benin. Benin City, Nigeria. Pp:110-185. 
Oni, B \& Dabalen, O, (2000). Labour Market Prospects of University Graduates in Nigeria. Abuja: The World Bank.

OSSCE, (2014).Osun State College of Education Ila-Orangun 1979-2014. A celebration of thirty-five years of exploits and landmark achievements.

Pannogan, Odette C. \& Dennis P. Ocampo. (2016). "Tracer Study of Bachelor of Arts Graduates Major in English" in International Journal of Advanced Research in Management and Social Sciences, 5(1). Retrieved from: http://www.garph.co.uk/IJARMSS/Jan2016/21.pdf

Ramirez, T.L., Leonardo T. Cruz \& Nida V. Alcantara. (2014). “Tracer Study of RTU

Graduates: An Analysis" in Researchers World: Journal of Arts, Science \& Commerce, 5(1) [January]. Retrieved from http://www.researchersworld.com/vol5/issue1/Paper_09.

Rogayana, D.V. (2019). Retrospective Evaluation of the Science Education Program in a Philippine State University. International Journal of Innovation, Creativity and Change. 8(7), 352-359. Retrieved from www.ijicc.net

Rojas, T.T. \& Rojas, R.C. (2016). College of Education Graduate Tracer Study (GTS): Boon or Bane? European Scientific Journal, 12(16), 63-78. Retrieved from http://dx.doi.org/10.19044/esj.2016.v12n16p63

Schomburg, H (2003) Handbook for Graduate Tracer Studies: Centre for Research on Higher Education and Work, University of Kassel, Germany. Retrieved from http://www.qtafi.de/handbook_v2.pdf.

Technical Education (TE),(2010). Departmental Students Handbook for Technical Education 2010-2014. Ila-Orangun, TE.

Ugwounah, G.E. \& K.C. Omeje. (1998). Final Report of Tracer Study: Research Project on Higher Education and Work. Enugu: Institute for Development Studies, University of Nigeria, Enugu 